\title{
Tinjauan Fikih Muamalah dan UU No. 8 Tahun 1999 tentang Perlindungan Konsumen terhadap Transaksi Jual Beli Dropshipping pada Marketplace $\mathrm{X}$
}

\author{
Syifa Manzilla Tousiya*, Maman Surahman \\ Bandung, Indonesia. \\ *syifamt46@gmail.com, abuazkaalmadani@gmail.com
}

Prodi Hukum Ekonomi Syariah, Fakultas Syariah, Universitas Islam

\begin{abstract}
Dropshipping is a buying and selling system where Dropshipping actors commonly called dropshipper can sell goods without having to stock goods. In practice, Dropshipping transactions conducted by Bloomstore accounts through X's Marketplace feature are still lacking in the application of muamalah jurispruding and Law No. 8 of 1999 on Consumer Protection. This research aims to find out the application of muamalah jurispruding and Law No. 8 of 1999 on Dropshipping transactions conducted by Bloomstore store accounts. This research method uses descriptive qualitative methods with a case study approach and type of data fields research (direct research in the field). The data obtained based on observations and interviews is equipped with library data in the form of books and journals that support this research. The results of this study are Dropshipping activities carried out by $\mathrm{X}$ as the owner of Bloomstore store account has not been in accordance with the pillars and conditions determined based on muamalah jurispruding and provisions that must be considered by consumers and business actors stated in Law No. 8 of 1999 on Consumer Protection.
\end{abstract}

Keywords: Dropshipping, Fikih Muamalah, Law No. 8 of 1999.

Abstrak. Dropshipping merupakan sistem jual - beli dimana pelaku Dropshipping yang biasa disebut dropshipper bisa menjual barang tanpa harus menyetok barang. Dalam praktiknya, transaksi jual beli Dropshipping yang dilakukan oleh akun Bloomstore melalui fitur Marketplace X ini masih terdapat kekurangan dalam penerapan fikih muamalah dan Undang - Undang No. 8 tahun 1999 tentang Perlindungan Konsumen. Penelitian ini bertujuan untuk mengetahui penerapan fikih muamalah dan UU No. 8 tahun 1999 pada transaksi jual beli Dropshipping yang dilakukan oleh akun toko Bloomstore. Metode penelitian ini menggunakan metode kualitatif deskriptif dengan pendekatan studi kasus dan jenis data fields research (penelitian langsung di lapangan). Data yang diperoleh berdasarkan hasil observasi dan wawancara dilengkapi dengan data pustaka berupa buku dan jurnal yang mendukung penelitian ini. Hasil penelitian ini adalah aktivitas jual - beli Dropshipping yang dilakukan oleh X sebagai pemilik akun toko Bloomstore belum sesuai dengan rukun dan syarat yang ditentukan berdasarkan fikih muamalah dan ketentuan yang harus diperhatikan oleh konsumen dan pelaku usaha yang dinyatakan dalam UU No. 8 tahun 1999 tentang Perlindungan Konsumen.

Kata Kunci: Dropshipping, Fikih Muamalah, Undang - Undang No. 8 tahun 1999. 


\section{A. Pendahuluan}

Manusia sebagai makhluk sosial tidak dapat menghilangkan fitrahnya untuk saling berkaitan satu sama lain, salah satunya dengan cara melakukan kegiatan ekonomi melalui aktivitas jual beli. Jual beli merupakan tukar - menukar harta dengan harta dengan cara tertentu yang bertujuan untuk memindahkan kepemilikan barang.

Dalam islam Allah telah berfirman :

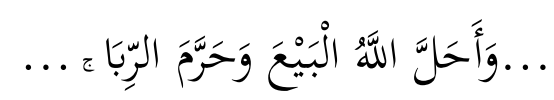

Artinya :

“... Dan Allah menghalalkan jual beli dan mengharamkan riba ..."

Seiring perkembangan teknologi, sistem jual beli pun semakin berkembang. Kini dengan adanya kemajuan teknologi aktivitas jual beli pun lebih mudah dengan sistem online. Di zaman modern ini, banyak sekali toko online atau $e$-commerce yang berkembang dengan pesat seperti Tokopedia, Shopee, Bukalapak, dll. Tahun 2016, aplikasi X meluncurkan fitur baru bernama Marketplace X. Marketplace X mampu memfasilitasi para penggunanya untuk bertransaksi secara jual beli secara online.

Transaksi jual beli online telah banyak diminati, terutama pada fitur Marketplace ini dikarenakan tidak memerlukan banyak modal, dan hanya perlu diiklankan dengan gambar dan spesifikasi barang yang akan dijual secara jelas. Bagi pemula yang akan memulai bisnis secara online, terdapat dua opsi yang bisa dipilih, yaitu reseller dan dropshipper. Reseller adalah sistem jual beli online dengan cara penjual harus menyetok barang, sedang Dropshipper adalah adalah sistem jual beli tanpa harus menyetok barang. Dalam transaksi jual beli Rasulullah saw bersabda:

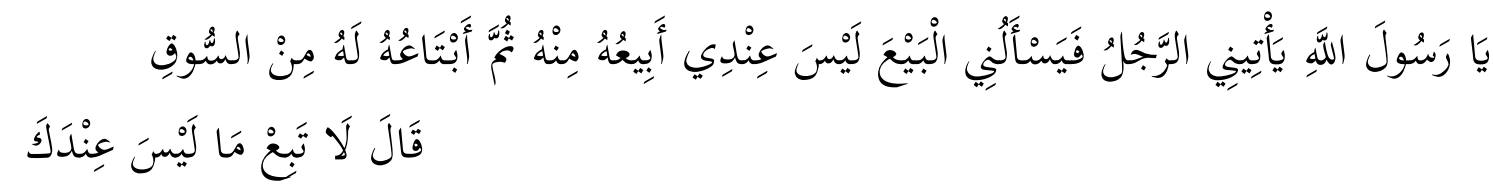

Artinya :

Wahai Rasulullah, ada seseorang yang mendatangiku lalu ia meminta agar aku menjual kepadanya barang yang belum aku miliki, agar aku menjual kepadanya?" Rasulullah shallallahu 'alaihi wa sallam menjawab, "Janganlah engkau menjual sesuatu yang tidak ada padamu (H.R Abu Daud, no. 3503; An - Nasai, no. 4613; Tirmidzi, no. 1232; dan Ibnu Majah, no. 2187. Syaikh Al - Albani mengatakan hadits ini shahih).

Maksud larangan hadits diatas adalah jual beli sesuatu yang bukan miliknya ketika akad itu berlangsung, jual beli barang yang belum diserahterimakan, dan semakna dengan jual beli barang orang lain tanpa izin karena pada saat ini tidak diketahui bahwa yang memiliki barang tersebut mengizinkan atau tidak. Dalam UU No. 8 tahun 1999 diatur bagaimana pelaku usaha semestinya memberikan hak yang harus didapatkan oleh konsumen, agar kedua belah pihak merasa nyaman dan tidak ada yang merasa dirugikan.

Dalam UU No. 8 tahun 1999 terdapat kurang lebih empat pasal yang menyinggung mengenai hak konsumen, kewajiban pelaku usaha dan hal - hal yang dilarang dilakukan oleh pelaku usaha. Tentunya keempat pasal tersebut harus diperhatikan oleh pihak yang melakukan kegiatan jual beli.

Dari sekian banyak pengguna Marketplace X, salah satunya adalah X (nama disamarkan) pemilik akun X Bloomstore yang telah menjadi dropshipper selama dua tahun sejak 2019. X berdomisili di Desa Cangkuang Kabupaten Garut Jawa Barat. X mengunggah foto produk yang didapatkan dari aplikasi $e$-commerce untuk diiklankan di fitur Marketplace X. X menjual produk dengan cara mengunggah foto di fitur tersebut padahal X bukanlah seorang agen yang ditunjuk langsung oleh produsen. Disamping itu, X mencantumkan harga yang tidak sesuai dengan harga yang sebenar benarnya, $\mathrm{X}$ mencantumkan harga jauh dibawah harga pasar demi menarik perhatian konsumen. Contoh Kasus : X menjual dompet seharga Rp. 150.000 rupiah, namun untuk menarik perhatian konsumen, $\mathrm{X}$ hanya 
mencantumkan Rp. 50, sehingga banyak konsumen yang salah sangka dan merasa dibohongi. $\mathrm{X}$ berdalih bahwa keterangan tersebut merupakan stok barang. Konsumen yang merasa dirugikan, mengurungkan niatnya untuk membeli produk di akun toko Bloomstore. Hal yang menarik untuk diteliti diantaranya adalah $\mathrm{X}$ menjual barang yang tidak dimiliki olehnya, $\mathrm{X}$ mengunggah barang tanpa seizin pemilik barang (produsen / supplier), $\mathrm{X}$ bukanlah seorang agen atau member resmi dari toko supplier, $\mathrm{X}$ menarik perhatian konsumen dengan cara mencantumkan harga yang tidak benar.

Berdasarkan latar belakang diatas, maka perumusan masalah dalam penelitian ini adalah sebagai berikut:

1. Bagaimana Tinjauan Fikih Muamalah dan UU No. 8 tahun 1999 tentang Perlindungan Konsumen tentang Jual Beli?

2. Bagaimana Praktik jual beli dengan sistem dropship yang dilakukan oleh akun Bloomstore pada fitur Marketplace X?

3. Bagaimana Tinjauan Fikih Muamalah dan UU No. 8 tahun 1999 tentang Perlindungan Konsumen terhadap transaksi jual beli Dropshipping yang dilakukan X melalui akun toko Bloomstore pada fitur Marketplace X?

Selanjutnya tujuan dalam penelitian ini adalah sebagai berikut:

1. Mengetahui bagaimana fikih muamalah dan UU No. 8 tahun 1999 mengatur mengenai sistem jual beli.

2. Mengetahui bagaimana proses praktik jual beli dengan system dropship yang dilakukan $\mathrm{X}$ di akun toko Bloomstore pada fitur Marketplace X.

3. Mengetahui tinjauan fikih muamalah dan UU No. 8 tahun 1999 tehadap transaksi jual beli dropship yang dilakukan X melalui akun toko Bloomstore pada fitur Marketplace $\mathrm{X}$.

\section{B. Metodologi Penelitian}

\section{Pendekatan Penelitian}

Penelitian ini adalah penelitian kualitatif. Penelitian kualitatif bisa dipahami sebagai prosedur riset yang memanfaatkan data deskriptif, berupa kata - kata tertulis atau lisan dari orang dan pelaku yang diamati. Penelitian ini adalah penilitian kualitatif yang bersifat deskriptif yaitu penelitian yang diarahkan untuk memberi gejala, fakta, atau kejadian scara sistematis dan akurat.

\section{Jenis Data Penelitian}

Jenis data yang digunakan adalah yuridis normatif, yaitu merupakan suatu pendekatan yang dilakukan berdasarkan dari bahan hukum yang dilakukan dengan cara penulis memahami dan menelaah teori, konsep, serta asas hukum dan peraturan perundang - undangan yang berhubungan / berkaitan dengan penelitian ini.

\section{Sumber Data Penelitian}

Sumber data penelitian diperoleh dari data primer dan data sekunder. Data Primer didapatkan dari hasil observasi dan wawancara. Sedangkan Data Sekunder didapatkan dari Studi Literatur buku - buku dan jurnal terkait dengan penelitian.

\section{Teknik Pengumpulan Data}

Dalam penelitian ini, teknik pengumpulan data dilakukan dengan observasi secara langsung ke tempat Dropshipper melakukan aktivitas jual beli secara online, hasil wawancara langsung yang dilakukan dengan dua pemilik akun toko dropship di Marketplace X, juga studi literatur dari buku dan jurnal - jurnal yang menunjang penelitian.

\section{Teknik Analisis Data}

Penelitian ini menggunakan teknik analisis deduktif, dimana penulis menyesuaikan fakta yang terjadi di lapangan dengan teori yang digunakan. 


\section{Hasil Penelitian dan Pembahasan}

\section{Tinjauan Fikih Muamalah}

Jual beli merupakan transaksi tukar - menukar harta dengan harta menggunakan cara tertentu yang bertujuan untuk memindahkan kepemilikkan. Dasar hukum jual beli salah satunya ada dalam Q.S Al - Baqarah (2) ayat 275:

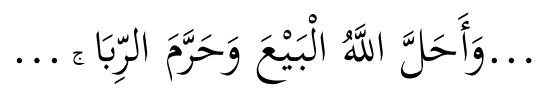

Artinya:

"... Dan Allah menghalalkan jual beli dan mengharamkan riba ..."

1. Rukun Jual Beli

a. Pihak - pihak yang melakukan jual - beli (ba'i dan musytari)

b. Pernyataan kehendak pihak - pihak (shighat al - aqd)

c. Objek jual beli (mabi' termasuk harga/tsaman)

d. Karakteristik jual beli, yaitu pemindahan kepemilikan dalam rangka pemenuhan kebutuhan yang berupa barang.

2. Syarat jual beli

Syarat shigat lafadz ijab qabul

a. Akad jual beli harus dinyatakan secara tegas dan jelas serta dipahami dan dimengerti oleh penjual dan pembeli.

b. Akad jual beli boleh dilakukan secara lisan, tulisan, isyarat, dan perbuatan/tindakan, serta dapat diajukan secara elektronik.

Syarat bagi penjual dan pembeli (Aqidain)
a. Berakal
b. Baligh
c. Tidak pemboros
d. Atas kemauan sendiri
e. Yang melakukan akad adalah orang yang berbeda

Syarat barang yang diperjualbelikan

a. Barang tersebut harus suci

b. Barang tersebut dapat dimanfaatkan

c. Barang tersebut merupakan milik orang yang meakukan akad

d. Barang tersebut harus diketahui kondisinya

e. Barang yang diakadkan ada ditangan

f. Barang tersebut mampu diserahterimakan

Syarat harga

a. Harga yang disepakati harus jelas jumlahnya

b. Waktu pembayarannya harus jelas

c. Apabila jual beli dengan sistem barter, maka barang yang dipertukarkannya bukan barang yang haram

Dalam setiap transaksi, pelaku usaha perlu memerhatikan setiap rukun dan syarat jual beli yang telah diatur dalam fikih muamalah. Begitupun dalam transaksi jual beli secara online, rukun dan syarat harus diperhatikan demi terjaganya hukum dari jual beli tersebut. Jual beli menurut fikih muamalah adalah jual beli yang memenuhi rukun dan syarat yang telah ditentukan, apabila ada salah satu syarat atau rukun yang cedera, maka hukum jual beli itu pun berubah.

Pada transaksi jual beli sistem Dropshipping yang dilakukan oleh X melalui akun toko Bloomstore di Marketplace X, dapat diketahui bahwa X mengunggah foto produk yang diambil dari salah satu laman $e$-commerce yang disukainya tanpa seizin pemilik barang, dan mengunggahnya pada fitur Marketplace X.

Dari hasil analisa penulis terkait rukun dan syarat jual beli diatas, apabila dikaitkan dengan transaksi jual beli dropship yang dilakukan oleh $\mathrm{X}$, maka jelas terdapat kekurangan dalam pemenuhan ketentuan syarat jual beli yang ditentukan oleh fikih muamalah. X bukanlah pemilik asli dari barang tersebut, yang mana barang tersebut masih berada di tangan supplier dan X bukanlah seorang agen atau wakil yang diberi kekuasaan untuk menjualnya. Kekuarangan JRES is licensed under Creative Commons Attribution- 
tersebut terletak dari posisi kepemilikan barang. Sesuai dengan hadits Rasulullah saw:

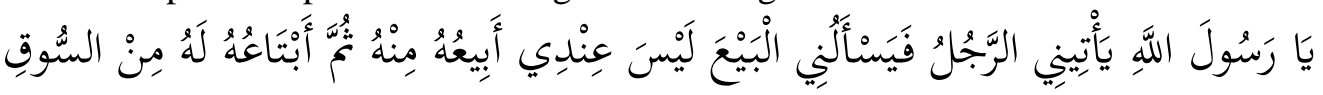

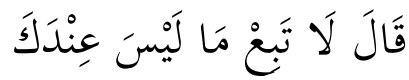

Artinya :

Wahai Rasulullah, ada seseorang yang mendatangiku lalu ia meminta agar aku menjual kepadanya barang yang belum aku miliki, agar aku menjual kepadanya?" Rasulullah shallallahu 'alaihi wa sallam menjawab, "Janganlah engkau menjual sesuatu yang tidak ada padamu (H.R Abu Daud, no. 3503; An - Nasai, no. 4613; Tirmidzi, no. 1232; dan Ibnu Majah, no. 2187. Syaikh Al - Albani mengatakan hadits ini shahih).

Hadits diatas menjelaskan bagaimana larangan menjual barang yang belum dimiliki secara penuh oleh penjual ketika akad berlangsung. Disesuaikan dengan fakta dilapangan transaksi jual beli dropship yang dilakukan oleh $\mathrm{X}$ sesuai dengan penjelasan diatas, maka dapat disimpulkan bahwa syarat pada system jual beli Dropshipping yang dilakukan oleh X pada fitur Marketplace X merupakan syarat yang cidera dan hukumnya tidak sah.

\section{Skema Praktik Jual Beli Dropshipping}

1. Skema praktik jual beli Dropshipping pada umumnya

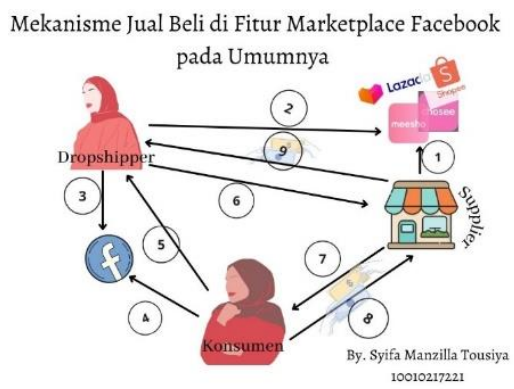

Gambar 1. Mekanisme Jual Beli di Fitur Marketplace X pada Umumnya

a. Supplier mengunggah foto produk/barang yang dijualnya pada e-commerce yang supplier minati untuk bekerja sama.

b. Dropshipper meminta izin kepada Supplier untuk bekerja sama dalam menawarkan produk milik Supplier pada Marketplace X, Dropshipper juga meminta izin untuk mengambil foto produk yang diunggah supplier pada laman Marketplace X. Dropshipper akan melanjutkan aktivitas jual beli atas izin dari supplier.

c. Setelah diizinkan, dropshipper mengunggah foto produk pada laman Marketplace X dengan harga yang ditentukan sendiri oleh Dropshipper.

d. Konsumen yang tertarik untuk membeli produk, akan menghubungi dropshipper via Mesengger X, biasanya konsumen akan melakukan negosiasi harga dengan Dropshipper hingga sepakat.

e. Dropshipper memesan produk yang diinginkan konsumen pada Supplier dengan langsung memberikan alamat konsumen agar diproses segera pengirimannya.

f. Supplier mengirimkan barang pesanan konsumen dengan menggunakan nama dropshipper dan metode pembayaran yang dilakukan bisa berupa transfer via bank atau COD (Cash On Delivery)/Bayar di Tempat.

g. Pembayaran langsung masuk pada Supplier, dan keuntungan dropshipper akan dikirimkan langsung oleh supplier.

2. Skema jual beli Dropshipping oleh X di akun toko Bloomstore 


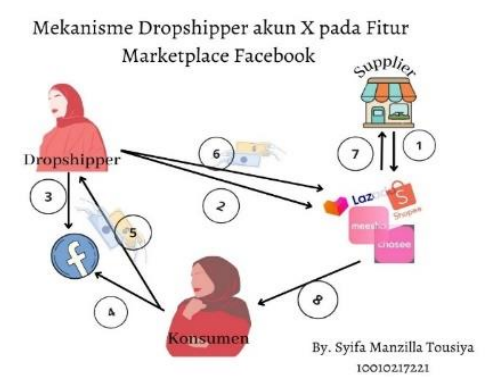

Gambar 2. Mekanisme Dropshipper Akun X pada Fitur Marketplace X

Pada praktiknya, berikut mekanisme jual beli sistem Dropshipping yang dilakukan oleh $\mathrm{X}$ melalui akun toko Bloomstore pada fitur Marketplace X:

a. Supplier mengunggah foto produk/barang nya pada $e$-commerce (Contoh : Shopee, Lazada, Bukalapak, dll)

b. Dropshipper (X) mengambil foto produk/barang dari akun $e$-commerce yang diminati oleh dropshipper tanpa izin supplier terlebih dahulu.

c. Dropshipper (X) tersebut mengunggah foto produk/barang pada laman akun Bloomstore miliknya di fitur Marketplace X untuk dijual.

d. Konsumen yang tertarik akan langsung menghubungi dropshipper dengan mengirim pesan melalui fitur Mesengger pada dropshipper.

e. Konsumen yang tertarik, akan langsung bertransaksi dengan dropshipper dan mengirim sejumlah uang pada rekening dropshipper.

f. Setelah uang diterima, dropshipper baru memesankan barang pesanan konsumen melaui $e$-commerce (contoh : Shopee), dengan sistem pembayaran transfer. Dropshipper mengirimkan uang yang diterimanya dari konsumen pada rekening supplier dengan sistem yang telah ditentukan $e$ - commerce. Dropshipper telah memisahkan keuntungan yang didapatkan dengan harga pokok.

g. Pesanan masuk pada supplier melalui sistem $e$-commerce.

h. Supplier mengirimkan barang langsung ke alamat konsumen, dikarenakan dropshipper langsung memasukan alamat konsumen pada saat proses pemesanan di $e$-commerce tersebut.

\section{Undang - Undang No. 8 tahun 1999 tentang Perlindungan Konsumen}

Pasal 1 ayat 8 UU No. 8 Tahun 1999 tentang Perlindungan Konsumen menyebutkan bahwa "Perlindungan konsumen adalah segala upaya yang menjamin adanya kepastian hukum untuk memberi perlindungan kepada konsumen. Hukum perlindungan konsumen menurut Sidobahok adalah keseluruhan peraturan dan hukum yang mengatur hak dan kewajiban peraturan dan hukum yang mengatur hak dan kewajiban konsumen dan produsen yang timbul dalam usahanya untuk memenuhi kebutuhannya dan mengatur upaya untuk menjamin terwujudnya perlindungan hukum terhadap kepentingan konsumen.

Terdapat lima asas dalam perlindungan konsumen, yaitu 1) Asas manfaat,2) Asas keadilan, 3) Asas keseimbangan, 4) Asas keamanan dan keselamatan konsumen, dan 5) Asas kepastian hukum. Dalam pemenuhan kelima asas tersebut terdapat beberapa pasal yang menentukan etika bisnis seorang pelaku usaha dan konsumen.

Pada transaksi jual beli sistem Dropshipping yang terjadi pada akun toko Bloomstore yang dilakukan oleh $\mathrm{X}$ memiliki beberapa ketidaksesuaian dengan apa yang seharusnya diterapkan sesuai dengan UU No. 8 tahun 1999. X merekayasa harga jauh dibawah harga yang sebenarnya dengan berdalih angka tersebut merupakan stok barang. Hal ini bertentangan dengan Pasal 4 poin c 'hak atas informasi yang benar, jelas, dan jujur mengenai kondisi dan jaminan barang dan/atau jasa' dapat diartikan bahwa konsumen harus mendapatkan informasi yang sebenar - benarnya mengenai barang yang diminati. Disesuaikan dengan fakta pada transaksi jual beli dropship yang dilakukan oleh $\mathrm{X}$ melalui akun toko Bloomstore miliknya, hal ini 
bertentangan. Karena $\mathrm{X}$ tidak memberikan informasi yang benar mengenai harga barang, sehingga konsumen secara otomatis kehilangan haknya untuk mendapatkan informasi yang jelas dan benar adanya.

Selain itu, masih pada Bab III UU No. 8 tahun 1999 bagian kedua yang membicarakan tentang hak dan kewajiban pelaku usaha, pada pembahasan kewajiban pelaku usaha poin $b$ berbunyi "memberikan informasi yang benar, jelas, dan jujur mengenai kondisi dan jaminan barang dan/atau jasa serta memberi penjelasan penggunaan perbaikan dan pemeliharaan". Maksudnya adalah pelaku usaha harus memberikan informasi yang jujur dan benar mengenai barang, dan hal tersebut merupakan hak yang harus didapatkan konsumen. Fakta yang penulis dapatkan pada transaksi Dropshipping X melalui akun Bloomstore pada Marketplace X, masih tidak memenuhi kewajibannya sebagai pelaku usaha yang jelas sudah diatur dalam UU No. 8 tahun 1999. Karena X masih belum memberikan informasi tentang barang yang sebenar benarnya.

Pada Bab IV UU No. 8 tahun 1999 membahas tentang perbuatan yang dilarang bagi pelaku usaha dimana pasal 9 ayat (1) poin e mengatakan bahwa pelaku usaha dilarang mengiklankan barang seolah - olah "barang dan/atau jasa tersebut tersedia". Sedangkan pada kenyataannya dalam transaksi jual beli dengan sistem dropship ini, barang tersebut belum ada di tangan penjual, dan penjual belum memilikinya. Berdasarkan fakta tersebut, terbukti bahwa $\mathrm{X}$ sebagai pemilik akun toko Bloomstore masih belum memenuhi atau masih melanggar Pasal 9 ayat (1) pon e UU No. 8 tahun 1999 tentang Perlindungan Konsumen.

Pada Bab IV UU No. 8 tahun 1999 membahas tentang perbuatan yang dilarang bagi pelaku usaha dimana pasal 10 berisi:

Pelaku usaha dalam menawarkan barang dan/atau jasa yang ditujukan untuk diperdagangkan dilarang menawarkan, mempromosikan, mengiklankan atau membuat pernyataan yang tidak benar atau menyesatkan mengenai:

1. Harga atau tarif suatu barang dan/atau jasa;

2. Kegunaan suatu barang dan/atau jasa;

3. Kondisi, tanggungan, jaminan, hak atau ganti rugi atas suatu barang dan/atau jasa;

4. Tawaran potongan harga atau hadiah menarik yang ditawarkan;

5. Bahaya penggunaan barang dan/atau jasa.

Disesuaikan dengan pasal diatas, $\mathrm{X}$ yang berlaku sebagai pelaku usaha jelas melanggar pasal 10 poin a dimana pelaku usaha dilarang menawarkan, mempromosikan, mengiklanlan atau membuat pernyataan yang tidak benar atau menyesatkan mengenai harga atau tarif suatu barang dan/atau jasa. Faktanya untuk menarik pelanggan $\mathrm{X}$ menawarkan barang dengan harga yang tidak sesuai dengan harga yang sebenarnya, dan berdalih bahwa itu hanyalah sisa stok yang tersedia.

Selain pasal 10, perbuatan yang dilarang bagi pelaku usaha juga diatur dalam Pasal 17. Dimana pada ayat (1) poin a berbunyi pelaku usaha periklanan dilarang memproduksi iklan yang "mengelabui konsumen mengenai kualitas, kuantitas, bahan, kegunaan, dan harga barang dan/atau tarif jasa serta ketepatan waktu penerimaan barang dan/atau jasa". Pada faktanya dikarenakan $\mathrm{X}$ bekerja seorang diri, dan jelas $\mathrm{X}$ bertanggung jawab pula terhadap mempromosikan foto yang akan dijadikan iklan/katalog pada fitur Marketplace X, maka X harus tetap memerhatikan hal ini. Pada faktanya rekayasa harga yang dilakukan $\mathrm{X}$ untuk menarik konsumen, jelas tidak sesuai dengan ketentuan pada pasal 17 yang melarang pelaku usaha menerbitkan iklan yang bersifat mengelabui konsumen termasuk harga barang.

\section{Kesimpulan}

Berdasarkan pemaparan mengenai praktik jual beli Dropshipping yang dilakukan oleh pemilik akun Bloomstore melalui Marketplace X, dapat diambil kesimpulan sebagai berikut:

1. Tinjauan Fikih Muamalah terhadap transaksi jual beli adalah jual beli dikatakan sah apabila transaksi jual beli tersebut telah memenuhi rukun dan syarat yang telah ditentukan menurut fikih muamalah, maka jual beli tersebut sah hukumnya karena rukun dan syaratnya terpenuhi tanpa adanya cidera. Jual beli menurut fikih muamalah adalah jual beli yang telah memenuhi rukun dan syarat jual beli. Rukun jual beli terdiri dari : 1) 
Penjual dan Pembeli, 2) Objek Jual beli, dan 3) Shighat (Ijab Qabul). Juga syarat jual beli terdiri dari beberapa kategori, terutama yang harus diperhatikan adalah syarat barang yang diperjualbelikan, dimana barang tersebut harus merupakan milik penjual, atau penjual merupakan orang yang ditunjuk oleh pemilik sebagai wakil untuk menjual barang tersebut atas izin langsung dari pemilik.

Tinjauan UU No. 8 tahun 1999 tentang Perlindungan Konsumen terhadap jual beli adalah bahwa jual beli yang baik adalah jual beli yang disertai dengan kesadaran dari para pelaku usaha dan konsumen dalam pelaksanaannya dapat membangun iklim berusaha yang sehat dan mendorong kualitas perusahaan menjadi perusahaan yang tangguh.

2. Praktik Jual beli sistem dropship yang dilakukan X melalui akun toko Bloomstore pada fitur Marketplace X adalah, X sebagai pemilik akun toko Bloomstore di Marketplace X menjual barang dengan cara mengunggah foto produk pada fitur Marketplace X tanpa seizin dari pemilik barang tersebut. X mendapatkan foto tersebut dari media sosial seperti Instagram, Lazada, Shopee, dll. Dengan begitu, terbukti bahwa $X$ tidak memiliki barang tersebut bahkan $\mathrm{X}$ menjualnya sebelum $\mathrm{X}$ membeli barang tersebut atau meminta izin secara langsung pada pemilim asli. Demi menarik perhatian konsumen, $\mathrm{X}$ merekayasa harga barang sehingga harga yang dicantumkan pada iklan di Marketplace X jauh dibawah harga yang sebenarnya. X berdalih bahwa harga tersebut merupakan sisa stok barang.

3. Tinjauan Fikih Muamalah terhadap praktik transaksi jual beli dengan sistem Dropshipping yang dilakukan oleh pemilik akun Bloomstore merupakan praktik jual beli yang belum memenuhi syarat jual beli, dimana barang masih berada di tangan supplier dan dropshipper bukanlah pemilik dari barang tersebut, dan bukan pula seseorang yang ditunjuk oleh supplier sebagai agen atau diberikan kuasa untuk menjual barang milik supplier. Dari fakta tersebut dapat diambil kesimpulan bahwa sistem jual beli yang dilakukan oleh X melalui akun Blomstore pada Marketplace X terciderai dari segi syarat jual beli dimana terdapat ketentuan syarat bahwa barang yang diperjualbelikan harus dimilik oleh penjual. Maka, transaksi jual beli dengan sistem dropship yang dilakukan oleh X melalui akun toko Bloomstore tidak sah karena tidak terpenuhinya syarat barang yang cidera.

Dengan hadits sabda Rasulullah saw:

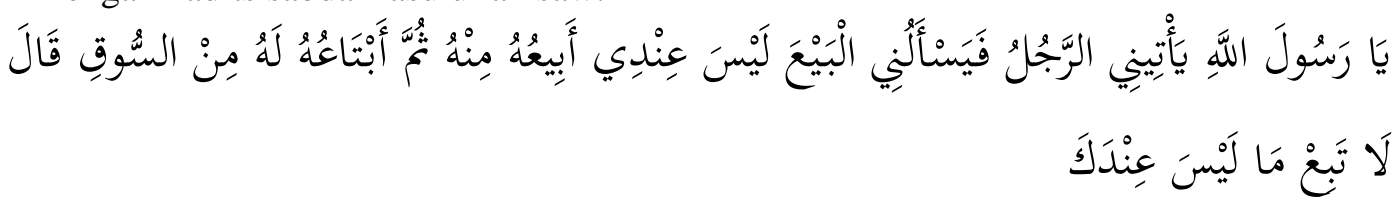

Artinya :

Wahai Rasulullah, ada seseorang yang mendatangiku lalu ia meminta agar aku menjual kepadanya barang yang belum aku miliki, agar aku menjual kepadanya?" Rasulullah shallallahu 'alaihi wa sallam menjawab, "Janganlah engkau menjual sesuatu yang tidak ada padamu” (H.R Abu Daud, no. 3503; An - Nasai, no. 4613; Tirmidzi, no. 1232; dan Ibnu Majah, no. 2187. Syaikh Al - Albani mengatakan hadits ini shahih).

Juga dalam pelaksanaan transaksi jual beli dengan sistem Dropshipping yang dilakukan $\mathrm{X}$ sebagai pemilik akun Bloomstore, terbukti masih melanggar beberapa ketentuan pasal yang telah diatur dalam Undang - Undang No. 8 Tahun 1999 tentang Perlindungan Konsumen. dimana telah diatur pada Bab III dan Bab IV mengenai hak konsumen, kewajiban pelaku usaha, dan hal - hal yang merupakan larangan bagi setiap pelaku usaha. Terdapat 5 (lima) pasal yang belum diterapkan dalam sistem jual beli Dropshipping yang dilakukan pemilik akun Bloomstore.

Ketidaksesuaian antara ketentuan yang ada dalam 5 (lima) pasal dengan fakta yang dilakukan oleh X sebagai pemilik akun toko Bloomstore pada fitur Marketplace X ini diperkuat oleh hadits yang dikutip oleh MA Mannan sebuah hadits Rasulullah SAW. yang artinya "Jauhkanlah dirimu dari banyak bersumpah dalam penjualan, karena sesungguhnya ia memanipulasi (iklan dagang) kemudian menghilangkan keberkahan" (HR. Muslim, An - Nasa'I 
dan Ibnu Majah). Hadits tersebut mengingatkan bahwa islam menganjurkan umatnya untuk mempromosikan suatu produk dan menetapkan suatu informasi berdasarkan kejujuran, tidak mengatakan kebohongan demi keuntungan semata.

\section{Acknowledge}

1. Kedua orang tua tercinta yaitu Papa Nazaruddin Muhammad Amin dan Mama Yani Suryani yang tidak pernah lelah memberikan do'a dan motivasi kepada penulis demi kelancaran aktivitas perkuliahan hingga dalam menyelesaikan penulisan skripsi ini.

2. Adik tercinta Khalisa Naura Naqya, yang selalu menemani, mendengarkan keluhan keluhan penulis selama perkuliahan dan memberikan semangat dan dukungan dalam penyelesaian skripsi ini.

3. Nenek tersayang yang selalu memberikan do'a dan semangat dalam penyusunan skripsi ini.

4. Bapak Prof. Dr. H. Edi Setiadi, SH., MH. Selaku rektor Universitas Islam Bandung.

5. Ibu Titin Suprihatin, Dra., M.Hum. Selaku Dekan Fakultas Syariah Universitas Islam Bandung.

6. Bapak H. Maman Surahman, Lc., M.Ag selaku dosen Pembimbing I yang selalu membimbing dengan sabar dan ikhlas, juga selalu memberikan masukan yang sangat bermanfaat dalam penyelesaian skripsi ini.

7. Bapak Arif Rijal Anshori, S.Sy., M.E selaku Ketua Program Studi Hukum Ekonomi Syariah serta selaku dosen Pembimbing II yang selalu membimbing dan memberikan arahan juga saran yang sangat bermanfaat dalam penyelesaian skripsi ini.

8. Ibu Intan Manggala, SE., MM selaku dosen wali yang senantiasa selalu memberikan motivasi, arahan, dan semangat sejak awal masa perkuliahan sampai menyelesaikan skripsi ini.

9. Ibu Popon Srisusilawati S.E.I., M.E.Sy., yang selalu memberikan arahan dan semangat sampai dengan penyelesaian skripsi ini.

10. Seluruh dosen Fakultas Syariah Universitas Islam Bandung uang sudah membimbing sejak penulis pertama kali menuntut ilmu di Fakultas Syariah sampai meraih gelar sarjana.

11. Pemilik Akun Toko Bloomstore dan Ridha Maulana yang telah berpartisipasi sebagai narasumber dalam penyelesaian skripsi ini.

12. Adik tercinta Dhien Izzati Hasanah, yang selalu menemani dan memberikan motivasi selama penulisan skripsi ini.

13. Kakak tercinta Teh Erika Meilani dan A Anggi Galih yang selalu memberikan semangat dan mendoakan kelancaran penyusunan skripsi ini.

14. Saudara tersayang Cheysya Maharani, Yuniar Dwi Septiane, Teh Ratna Ambarsari, dan A Aang Alamsyah yang selalu memberikan semangat dan mendoakan kelancaran penyusunan skripsi ini.

15. Seluruh keluarga besar penulis yang telah mendukung dan memberikan motivasi selama penulisan skripsi ini.

16. Sahabat tersayang Mega Trisyani dan Maulani Sepriyan, yang selalu saling memberikan motivasi dan berjuang bersama dalam aktivitas perkuliahan sampai dengan menyelesaikan program sarjana ini.

17. Teman seperjuangan Resya Wahyuni, Indah, Teh Istia, Annisa Yuliani, Fahmi Nuraisiyah, dan Tiana Apriani yang selalu sama sama memberikan semangat dalam penyusunan skripsi ini.

18. Teman - teman yang memberikan pelajaran berharga, Rini Apriani, Syifa Nurfadhilah, Alfadhilah Rizky yang selalu memotivasi dalam menyelesaikan skripsi ini.

19. Seluruh teman teman seperjuangan di Program Studi Hukum Ekonomi Syariah Fakultas Syariah Universitas Islam Bandung yang tidak bisa saya sebutkan satu persatu.

20. Dan teruntuk diri saya sendiri karna telah mampu menyelesaikan skripsi ini dengan segala macam hambatan dan ujian yang sangat nikmat, semoga selalu bersyukur. 


\section{Daftar Pustaka}

[1] Bariroh, Muflihatul. "Transaksi Jual Beli Dropshipping Dalam Perspektif Fiqh Muamalah." Jurnal Ahkam 4 No.2 (2016): 199-216.

[2] Bloomstore, X Pemilik Akun. "Wawancara Dengan Dropshipper Pemilik Akun Bloomstore," 2021.

[3] Cahyadi, Iwan Fahri. "Sistem Pemasaran Dropship Dalam Perspektif Islam." TAWAZUN: Journal of Sharia Economic Law 1, no. 1 (2018): 24.

[4] Celina Tri Siwi Kristiyanti. Hukum Perlindungan Konsumen. Jakarta: Sinar Grafika, 2008.

[5] Dewan Syariah Nasional Majelis Ulama Indonesia (DSN-MUI). "DEWAN SYARIAH NASIONAL-MAJELIS ULAMA INDONESIA NO:110/DSN-MUI/IX/2O17 Tentang Akad Jual Beli," no. 021 (2017): 1-6.

[6] Hardani, S.Pd., M.Si, M.Si Helmina Andriani, M.Si Jumari Ustiawaty, S.Si., Apt Evi Fatmi Utami, M.Farm., M.I.Kom Ria Rahmatul Istiqomah, M.Pd Roushandy Asri Fardani, S.Si., M.Sc Dhika Juliana Sukmana, S.Si., and Grad.Cert.Biotech Nur Hikmatul Auliya. Metode Penelitian Kualitatif Dan Kuantitatif. Edited by AK Husnu Abadi, A.Md. Cetakan Ke. Yogyakarta: CV. Pustaka Ilmu Group Yogyakarta, 2020.

[7] Indonesia, Republik. "UU No 8 Tahun 1999 Perlindungan Konsumen" (2004): 1-6.

[8] Maulana, Ridha. "Wawancara Dengan Dropshipper Pemilik Akun 'Ridha Maulana,"” 2021.

[9] N. Eva Fauziah, Dra., M.Ag, M.E.Sy Eva Misfah, S.E.I., M.E.Sy Popon Srisusilawati, S.E.I., M.S.I Fahmi Fatwa Rosyadi Satria Hamdani, M.Hum Irma Yulita Silviany, S.S., and M.H Liza Dzulhijjah, S.H. Pedoman Penulisan Proposal Dan Skripsi 2020. Bandung: Fakultas Syariah Unisba, 2020.

[10] Panji Adam, S.sy., M.H. Fikih Muamalah Adabiyah. Bandung: PT. Refika Aditama, 2018.

[11] Prof. Dr. H. Jaih Mubarok, S.E., M.H., M. Ag., and M.Ag Dr. Hasanudin. Fikih Muamalah Maliyah Akad Jual Beli. Bandung: Simbiosa Rekatama Media, 2018.

[12] Ristekdikti. Modul Rancangan Penelitian, 2019.

[13] Shobirin. "Jual Beli Dalam Pandangan Islam." Jurnal Bisnis dan Manajemen Islam Vo. 3 No.2 (2015). 